\title{
11. BIRTH DEFECTS
}

\section{Birth defects among stillborn and live born infants}

A birth defect is any structural defect detected during pregnancy or at birth, excluding birth injuries and minor anomalies such as skin tags, positional talipes, birthmarks, or clicky hips. Descriptions of some common birth defects are shown in Appendix 1. A list of common exclusions is shown in Appendix 2.

From 1 January 1998, doctors, hospitals and laboratories are required to notify birth defects detected during pregnancy, at birth, or up to one year of life under the NSW Public Health Act 1991. Information reported is included in the NSW Birth Defects Register (BDR). This chapter reports birth defects detected during pregnancy or in the first year of life for 2000-2005 and birth defects detected during pregnancy or at birth for 2006.

\section{Trends in reported birth defects}

Between 2000 and 2004, the reported proportion of infants with birth defects has remained stable at about 2 per cent, with a slight decline in 2005 to 1.8 per cent (Table 145). In 2006, 792 cases of birth defects detected during pregnancy or at birth were reported.

\section{Birth defects by diagnostic category}

The most common categories of birth defects for births of more than 20 weeks gestation or with a birth weight greater than 400 grams are presented in Table 146. Birth defects are classified using the British Paediatric
Association (BPA) Classification of Diseases, which is primarily organised by body system. For infants with more than one defect, each defect is counted separately. The number of birth defects reported therefore exceeds the number of affected infants.

In 2000-2006, defects of the cardiovascular system were most commonly reported, followed by defects of the musculoskeletal system and defects of the genitourinary system (Table 146). This is a similar pattern to previous years. In 2005, the overall rate of defects was slightly lower than the previous 5 years $(31.9$ versus 36.3 per 1,000$)$.

\section{TABLE 145}

BIRTH DEFECT CASES, NSW 2000-2006\#

\begin{tabular}{|cccc|}
\hline Year & Birth defect cases & Births & Rate/1000 births \\
\hline 2000 & 1858 & 87140 & 21.3 \\
2001 & 1775 & 85286 & 20.8 \\
2002 & 1739 & 85398 & 20.4 \\
2003 & 1761 & 85853 & 20.5 \\
2004 & 1750 & 85016 & 20.6 \\
2005 & 1621 & 89840 & 18.0 \\
2006 & 792 & 92038 & 8.6 \\
\hline
\end{tabular}

Source: NSW Birth Defects Register. Centre for Epidemiology and Research. NSW Department of Health.

\# For 2000-2005, cases reported during pregnancy and up to one year of age are included. For 2006, cases reported during pregnancy or at birth are reported.

\section{TABLE 146}

\begin{tabular}{|c|c|c|c|c|c|c|c|c|}
\hline \multirow[t]{2}{*}{ Diagnostic category } & \multicolumn{4}{|c|}{ No. defects } & \multicolumn{4}{|c|}{ Rate/1,000 births } \\
\hline & 2000-2004 & 2005 & 2006 & 2000-2006 & 2000-2004 & 2005 & 2006 & 2000-2006 \\
\hline \multicolumn{9}{|l|}{ Defects of nervous system } \\
\hline Anencephaly & 51 & 10 & 7 & 68 & 0.1 & 0.1 & 0.1 & 0.1 \\
\hline Spina Bifida & 128 & 25 & 18 & 171 & 0.3 & 0.3 & 0.2 & 0.3 \\
\hline Encephalocele & 31 & 5 & 5 & 41 & 0.1 & 0.1 & 0.1 & 0.1 \\
\hline Microcephaly & 117 & 16 & 6 & 139 & 0.3 & 0.2 & 0.1 & 0.2 \\
\hline Congenital hydrocephalus & 180 & 26 & 20 & 226 & 0.4 & 0.3 & 0.2 & 0.4 \\
\hline Other nervous system defects & 316 & 39 & 26 & 381 & 0.7 & 0.4 & 0.3 & 0.6 \\
\hline TOTAL & 823 & 121 & 82 & 1026 & 1.9 & 1.3 & 0.9 & 1.7 \\
\hline \multicolumn{9}{|l|}{ Defects of eye } \\
\hline Anophthalmos-microphthalmos & 56 & 12 & 3 & 71 & 0.1 & 0.1 & 0.0 & 0.1 \\
\hline Buphthalmos-congenital glaucoma & 25 & 9 & 1 & 35 & 0.1 & 0.1 & 0.0 & 0.1 \\
\hline Congenital cataract & 67 & 21 & 3 & 91 & 0.2 & 0.2 & 0.0 & 0.1 \\
\hline Other eye defects & 164 & 36 & 14 & 214 & 0.4 & 0.4 & 0.2 & 0.4 \\
\hline TOTAL & 312 & 78 & 21 & 411 & 0.7 & 0.9 & 0.2 & 0.7 \\
\hline \multicolumn{9}{|l|}{ Defects of ear, face and neck } \\
\hline Absence-stricture auditory canal & 51 & 10 & 8 & 69 & 0.1 & 0.1 & 0.1 & 0.1 \\
\hline Absent auricle & 8 & 2 & - & 10 & 0.0 & 0.0 & & 0.0 \\
\hline Defects of face and neck & 44 & 3 & 5 & 52 & 0.1 & 0.0 & 0.1 & 0.1 \\
\hline Other ear defects & 79 & 8 & 14 & 101 & 0.2 & 0.1 & 0.2 & 0.2 \\
\hline TOTAL & 182 & 23 & 27 & 232 & 0.4 & 0.3 & 0.3 & 0.4 \\
\hline
\end{tabular}




\section{TABLE 146}

BIRTH DEFECTS AMONG STILLBIRTHS AND LIVE BORN INFANTS BY DIAGNOSTIC CATEGORY, NSW 2000-2006\#

$\begin{array}{lll}\text { Diagnostic category } & \text { No. defects } & \text { Rate/1,000 births }\end{array}$

\begin{tabular}{|c|c|c|c|c|c|c|c|c|}
\hline \multirow{2}{*}{\multicolumn{9}{|c|}{ Defects of cardiovascular system }} \\
\hline & & & & & & & & \\
\hline Transposition of great vessels & 222 & 56 & 22 & 300 & 0.5 & 0.6 & 0.2 & 0.5 \\
\hline Tetralogy of Fallot & 148 & 27 & 13 & 188 & 0.3 & 0.3 & 0.1 & 0.3 \\
\hline Ventricular septal defect & 869 & 138 & 73 & 1080 & 2.0 & 1.5 & 0.8 & 1.8 \\
\hline Atrial septal defect & 827 & 138 & 84 & 1049 & 1.9 & 1.5 & 0.9 & 1.7 \\
\hline Heart valve defects & 552 & 111 & 46 & 709 & 1.3 & 1.2 & 0.5 & 1.2 \\
\hline Patent ductus arteriosus $>37$ weeks & 445 & 87 & 39 & 571 & 1.0 & 1.0 & 0.4 & 0.9 \\
\hline Coarctation of aorta & 203 & 40 & 23 & 266 & 0.5 & 0.4 & 0.2 & 0.4 \\
\hline Other defects of aorta & 101 & 25 & 17 & 143 & 0.2 & 0.3 & 0.2 & 0.2 \\
\hline Defects of pulmonary artery & 141 & 32 & 19 & 192 & 0.3 & 0.4 & 0.2 & 0.3 \\
\hline Other cardiovascular defects & 709 & 146 & 79 & 934 & 1.7 & 1.6 & 0.9 & 1.5 \\
\hline TOTAL & 4217 & 800 & 415 & 5432 & 9.8 & 8.9 & 4.5 & 8.9 \\
\hline \multicolumn{9}{|l|}{ Defects of respiratory system } \\
\hline Defects of nose & 59 & 11 & 8 & 78 & 0.1 & 0.1 & 0.1 & 0.1 \\
\hline Defects of larynx, trachea and bronchus & 49 & 6 & 1 & 56 & 0.1 & 0.1 & 0.0 & 0.1 \\
\hline Defects of lung & 70 & 19 & 11 & 100 & 0.2 & 0.2 & 0.1 & 0.2 \\
\hline TOTAL & 178 & 36 & 20 & 234 & 0.4 & 0.4 & 0.2 & 0.4 \\
\hline \multicolumn{9}{|l|}{ Defects of gastrointestinal system } \\
\hline Cleft palate only & 406 & 95 & 40 & 541 & 0.9 & 1.1 & 0.4 & 0.9 \\
\hline Cleft lip only & 151 & 23 & 29 & 203 & 0.4 & 0.3 & 0.3 & 0.3 \\
\hline Cleft palate and cleft lip & 223 & 34 & 38 & 295 & 0.5 & 0.4 & 0.4 & 0.5 \\
\hline Oesophageal atresia only & 11 & 4 & 3 & 18 & 0.0 & 0.0 & 0.0 & 0.0 \\
\hline Tracheo-oesophageal fistula (TOF) only & 19 & 5 & 4 & 28 & 0.0 & 0.1 & 0.0 & 0.0 \\
\hline Oesophageal atresia with TOF & 70 & 17 & 15 & 102 & 0.2 & 0.2 & 0.2 & 0.2 \\
\hline Atresia/stenosis of small intestine & 133 & 30 & 14 & 177 & 0.3 & 0.3 & 0.2 & 0.3 \\
\hline Atresia/stenosis of anus & 115 & 26 & 18 & 159 & 0.3 & 0.3 & 0.2 & 0.3 \\
\hline Other gastrointestinal defects & 464 & 86 & 30 & 580 & 1.1 & 1.0 & 0.3 & 0.9 \\
\hline TOTAL & 1592 & 320 & 191 & 2103 & 3.7 & 3.6 & 2.1 & 3.4 \\
\hline \multicolumn{9}{|l|}{ Defects of genitourinary system } \\
\hline Defects of female genitals & 55 & 14 & 9 & 78 & 0.1 & 0.2 & 0.1 & 0.1 \\
\hline Undescended testis & 305 & 36 & 16 & 357 & 0.7 & 0.4 & 0.2 & 0.6 \\
\hline Hypospadias & 816 & 146 & 80 & 1042 & 1.9 & 1.6 & 0.9 & 1.7 \\
\hline Epispadias & 11 & & 3 & 14 & 0.0 & . & 0.0 & 0.0 \\
\hline Chordee & 134 & 28 & 20 & 182 & 0.3 & 0.3 & 0.2 & 0.3 \\
\hline Indeterminate sex-ambiguous genitalia & 54 & 12 & 9 & 75 & 0.1 & 0.1 & 0.1 & 0.1 \\
\hline Renal agenesis-dysgenesis & 197 & 29 & 26 & 252 & 0.5 & 0.3 & 0.3 & 0.4 \\
\hline Obstructive defects of renal pelvis and ureter & 703 & 118 & 36 & 857 & 1.6 & 1.3 & 0.4 & 1.4 \\
\hline Other genitourinary system defects & 615 & 122 & 59 & 796 & 1.4 & 1.4 & 0.6 & 1.3 \\
\hline TOTAL & 2890 & 505 & 258 & 3653 & 6.7 & 5.6 & 2.8 & 6.0 \\
\hline \multicolumn{9}{|l|}{ Defects of musculoskeletal system } \\
\hline Congenital dislocation of the hips & 682 & 140 & 28 & 850 & 1.6 & 1.6 & 0.3 & 1.4 \\
\hline Talipes equinovarus & 344 & 73 & 26 & 443 & 0.8 & 0.8 & 0.3 & 0.7 \\
\hline Polydactyly & 484 & 93 & 79 & 656 & 1.1 & 1.0 & 0.9 & 1.1 \\
\hline Syndactyly & 86 & 25 & 18 & 129 & 0.2 & 0.3 & 0.2 & 0.2 \\
\hline Reduction deformities of limbs & 226 & 50 & 49 & 325 & 0.5 & 0.6 & 0.5 & 0.5 \\
\hline Craniosynostosis & 276 & 32 & 3 & 311 & 0.6 & 0.4 & 0.0 & 0.5 \\
\hline Diaphragmatic hernia & 119 & 28 & 20 & 167 & 0.3 & 0.3 & 0.2 & 0.3 \\
\hline Exomphalos & 74 & 11 & 9 & 94 & 0.2 & 0.1 & 0.1 & 0.2 \\
\hline Gastroschisis & 90 & 17 & 20 & 127 & 0.2 & 0.2 & 0.2 & 0.2 \\
\hline Other musculoskeletal defects & 784 & 137 & 106 & 1027 & 1.8 & 1.5 & 1.2 & 1.7 \\
\hline TOTAL & 3165 & 606 & 358 & 4129 & 7.4 & 6.7 & 3.9 & 6.8 \\
\hline Defects of integumentary system & 320 & 36 & 19 & 375 & 0.7 & 0.4 & 0.2 & 0.6 \\
\hline Cystic hygroma & 50 & 13 & 3 & 66 & 0.1 & 0.1 & 0.0 & 0.1 \\
\hline \multicolumn{9}{|l|}{ Chromosomal defects } \\
\hline Trisomy 21 & 511 & 73 & 55 & 639 & 1.2 & 0.8 & 0.6 & 1.0 \\
\hline Trisomy 13 & 36 & 6 & 7 & 49 & 0.1 & 0.1 & 0.1 & 0.1 \\
\hline Trisomy 18 & 85 & 16 & 18 & 119 & 0.2 & 0.2 & 0.2 & 0.2 \\
\hline Turner syndrome & 70 & 14 & 7 & 91 & 0.2 & 0.2 & 0.1 & 0.1 \\
\hline Other chromosomal defects & 300 & 70 & 18 & 388 & 0.7 & 0.8 & 0.2 & 0.6 \\
\hline TOTAL & 1002 & 179 & 105 & 1286 & 2.3 & 2.0 & 1.1 & 2.1 \\
\hline Situs inversus & 27 & 5 & 1 & 33 & 0.1 & 0.1 & 0.0 & 0.1 \\
\hline Congenital malformation syndromes & 201 & 34 & 19 & 254 & 0.5 & 0.4 & 0.2 & 0.4 \\
\hline Congenital cytomegalovirus infection & 2 & 0 & 0 & 2 & 0.0 & 0.0 & 0.0 & 0.0 \\
\hline Non-immune hydrops foetalis & 110 & 20 & 10 & 140 & 0.3 & 0.2 & 0.1 & 0.2 \\
\hline Other and unspecified birth defects & 491 & 93 & 15 & 599 & 1.1 & 1.0 & 0.2 & 1.0 \\
\hline TOTAL & 15562 & 2869 & 1544 & 19975 & 36.3 & 31.9 & 16.8 & 32.7 \\
\hline
\end{tabular}

Source: NSW Birth Defects Register. Centre for Epidemiology and Research. NSW Department of Health.

\# For 2000-2005, cases reported during pregnancy and up to one year of age are included. For 2006, cases reported during pregnancy or at birth are reported. 


\section{Infant characteristics}

In the period 2000-2006, a single defect was reported in 62.4 per cent of infants, 2 defects in 17.8 per cent, 3 defects in 8.3 per cent, and 4 or more defects in 11.6 per cent of cases. The sex was male in 57.9 per cent of infants, female in 41.6 per cent, indeterminate in 0.3 per cent of infants, and was not stated for 0.2 per cent.

Birth defects were more common in preterm and postterm infants than infants born at term (Table 147). Birth defects were also more common in infants born of a multiple pregnancy than a singleton pregnancy: in 20002006, 1.8 per cent of singleton babies, 2.4 per cent of twins, and 3.6 per cent of triplets were born with a birth defect.

About 11 per cent of infants born with birth defects died in the perinatal period, over half of which were stillbirths (Table 148). These figures comprise all birth defect cases, including those where the cause of death may not be directly related to the birth defect(s). By comparison, the perinatal mortality rate among all births reported to the NSW Midwives Data Collection was less than one per cent in 2006 (see Chapter 4).

\section{TABLE 147}

\section{BIRTH DEFECT CASES BY GESTATIONAL AGE, NSW 2000-2006\#}

\begin{tabular}{|c|c|c|c|c|c|c|c|c|c|}
\hline \multirow[t]{2}{*}{$\begin{array}{l}\text { Gestational age } \\
\text { (weeks) }\end{array}$} & \multicolumn{9}{|c|}{ Year } \\
\hline & No. & $\%$ & No. & $\%$ & No. & $\%$ & No. & $\%$ & Rate/1,000 births \\
\hline $20-27$ & 590 & 6.6 & 108 & 6.7 & 78 & 9.8 & 776 & 6.9 & 181.9 \\
\hline $28-31$ & 276 & 3.1 & 36 & 2.2 & 31 & 3.9 & 343 & 3.0 & 75.5 \\
\hline $32-36$ & 1062 & 12.0 & 230 & 14.2 & 114 & 14.4 & 1406 & 12.4 & 40.0 \\
\hline $37-41$ & 6355 & 71.5 & 1111 & 68.5 & 555 & 70.1 & 8021 & 71.0 & 14.5 \\
\hline $42+$ & 183 & 2.1 & 25 & 1.5 & 13 & 1.6 & 221 & 2.0 & 16.6 \\
\hline Not stated & 417 & 4.7 & 111 & 6.8 & 1 & 0.1 & 529 & 4.7 & - \\
\hline TOTAL & 8883 & 100.0 & 1621 & 100.0 & 792 & 100.0 & 11296 & 100.0 & 18.5 \\
\hline
\end{tabular}

Source: NSW Birth Defects Register. Centre for Epidemiology and Research. NSW Department of Health.

\# For 2000-2005, cases reported during pregnancy and up to one year of age are included. For 2006, cases reported during pregnancy or at birth are reported.

\section{TABLE 148}

\section{BIRTH DEFECT CASES BY PREGNANCY OUTCOME, NSW 2000-2006\#}

Pregnancy outcome Year

\begin{tabular}{lrrrrrrrr} 
& \multicolumn{2}{c}{$\mathbf{2 0 0 0 - 2 0 0 4}$} & \multicolumn{2}{c}{$\mathbf{2 0 0 5}$} & \multicolumn{2}{c}{$\mathbf{2 0 0 6}$} & \multicolumn{2}{c}{$\mathbf{2 0 0 0 - 2 0 0 6}$} \\
& \multicolumn{1}{c}{ No. } & \% & No. & \% & No. & \% & No. & \% \\
\hline Stillbirth & 571 & 6.4 & 114 & 7.0 & 83 & 10.5 & 768 & 6.8 \\
Liveborn-neonatal death & 358 & 4.0 & 58 & 3.6 & 51 & 6.4 & 467 & 4.1 \\
Liveborn-postneonatal death & 68 & 0.8 & 9 & 0.6 & 1 & 0.1 & 78 & 0.7 \\
Liveborn surviving & 7886 & 88.8 & 1440 & 88.8 & 657 & 83.0 & 9983 & 88.4 \\
TOTAL & 8883 & 100.0 & 1621 & 100.0 & 792 & 100.0 & 11296 & 100.0 \\
\hline
\end{tabular}

Source: NSW Birth Defects Register. Centre for Epidemiology and Research. NSW Department of Health.

\# For 2000-2005, cases reported during pregnancy and up to one year of age are included. For 2006, cases reported during pregnancy or at birth are reported. 


\section{Maternal characteristics}

After 35 years of age, the incidence of birth defects increased with increasing maternal age (Table 149). While the rate of birth defects is higher in older women, the majority of births occur in younger women. In 2000-2006, 72.1 per cent of babies with birth defects were born to women aged less than 35 years.
In 2000-2006, 330 babies of Aboriginal or Torres Strait Islander mothers were reported to have birth defects. The rate of birth defects among these babies was 20.6 per 1,000 compared with 17.0 per 1,000 for non-Aboriginal mothers

\section{TABLE 149}

BIRTH DEFECT CASES BY MATERNAL AGE, NSW 2000-2006\#

Maternal age (years) Year

\begin{tabular}{|lrrrrrrrrr} 
& \multicolumn{2}{c}{$\mathbf{2 0 0 0 - 2 0 0 4}$} & \multicolumn{2}{c}{$\mathbf{2 0 0 5}$} & \multicolumn{2}{c}{$\mathbf{2 0 0 6}$} & \multicolumn{2}{c}{$\mathbf{2 0 0 0 - 2 0 0 6}$} \\
& No. & $\%$ & No. & $\%$ & No. & $\%$ & No. & $\%$ & Rate/1,000 \\
\hline Under 20 & 361 & 4.1 & 62 & 3.8 & 39 & 4.9 & 462 & 4.1 & 18.5 \\
$20-24$ & 1239 & 13.9 & 223 & 13.8 & 126 & 15.9 & 1588 & 14.1 & 17.8 \\
$25-29$ & 2308 & 26.0 & 359 & 22.1 & 192 & 24.2 & 2859 & 25.3 & 16.4 \\
$30-34$ & 2530 & 28.5 & 439 & 27.1 & 267 & 33.7 & 3236 & 28.6 & 16.0 \\
$35-39$ & 1320 & 14.9 & 269 & 16.6 & 129 & 16.3 & 1718 & 15.2 & 17.3 \\
$40-44$ & 320 & 3.6 & 78 & 4.8 & 36 & 4.5 & 434 & 3.8 & 22.4 \\
$45+$ & 25 & 0.3 & 6 & 0.4 & 3 & 0.4 & 34 & 0.3 & 36.0 \\
Not stated & 780 & 8.8 & 185 & 11.4 & 0 & 0.0 & 965 & 8.5 & - \\
TOTAL & 8883 & 100.0 & 1621 & 100.0 & 792 & 100.0 & 11296 & 100.0 & 18.5 \\
\hline
\end{tabular}

Source: NSW Birth Defects Register. Centre for Epidemiology and Research. NSW Department of Health.

\# For 2000-2005, cases reported during pregnancy and up to one year of age are included. For 2006, cases reported during pregnancy or at birth are reported.

\section{Birth defects among terminations of pregnancy, spontaneous abortions and unknown outcomes of pregnancy}

In the period 2000-2006, on average about 300 terminations of pregnancy per year were reported to the NSW Birth Defects Register (Table 150). To date, 196 terminations of pregnancy have been reported to the Register for 2006.

This number is expected to increase as outcomes for mothers with defects detected during pregnancy in 2006 continue to be reported. Of the 1,919 terminations of pregnancy reported in 2000-2006, 1,480 (77.1 per cent) were associated with a chromosomal abnormality, the most common of which was Trisomy 21 (Down syndrome), and 192 (10.0 per cent) were associated with a neural tube defect (Tables 150 and 151).

For spontaneous abortions, cytogenetic analysis is only carried out in cases of habitual abortion; the numbers presented, therefore, underestimate the number of spontaneous abortions that occur due to birth defects. Descriptions of some diagnostic terms used here are included in Appendix 1.

\section{TABLE 150}

PREGNANCIES WITH FETUSES AFFECTED BY BIRTH DEFECTS RESULTING IN SPONTANEOUS ABORTION, TERMINATION OF PREGNANCY OR UNKNOWN OUTCOME, NSW 2000-2006

\begin{tabular}{|c|c|c|c|c|c|c|c|c|}
\hline \multirow[t]{2}{*}{ Pregnancy outcome } & \multicolumn{8}{|c|}{ Year } \\
\hline & 2000 & 2001 & 2002 & 2003 & 2004 & 2005 & 2006 & 2000-2006 \\
\hline & No. & No. & No. & No. & No. & No. & No. & No. \\
\hline Spontaneous abortion & 124 & 171 & 202 & 232 & 298 & 317 & 348 & 1692 \\
\hline $\begin{array}{l}\text { Termination of pregnancy less } \\
\text { than } 20 \text { weeks gestation }\end{array}$ & 262 & 257 & 285 & 312 & 305 & 302 & 196 & 1919 \\
\hline Unknown outcome & 22 & 19 & 7 & 18 & 38 & 29 & 0 & 133 \\
\hline TOTAL & 408 & 447 & 494 & 562 & 641 & 648 & 544 & 3744 \\
\hline
\end{tabular}




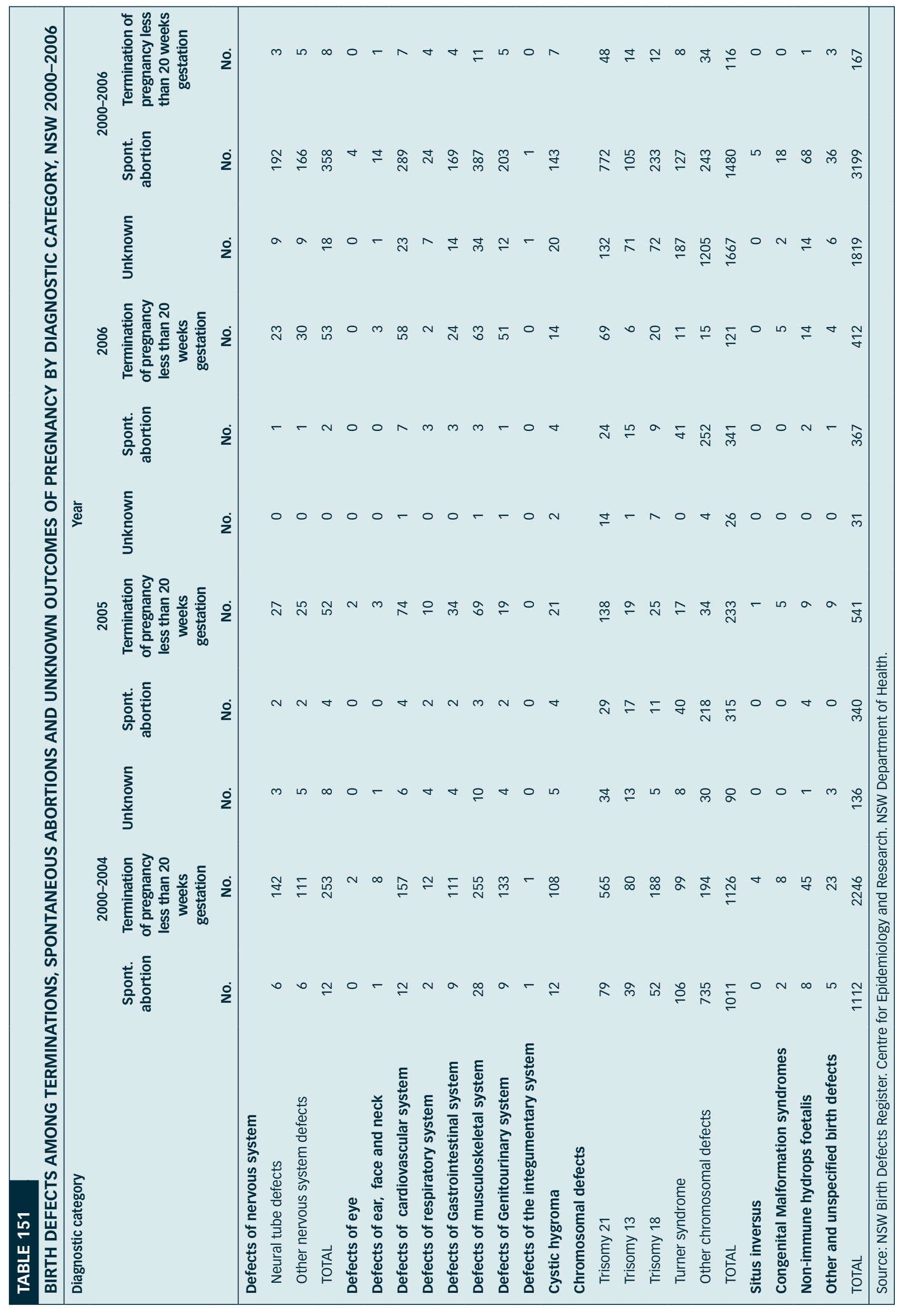




\section{Trends in selected birth defects}

Trends in a selection of common birth defects are shown in Table 152 and Figures 14 to 17. For 2000-2005, malformations reported up to one year of age are included; for 2006, malformations reported during pregnancy or at birth are included.

The reported number of live born and stillborn infants with neural tube defects was 41 in 2000 and 40 in 2005, and 30 have been reported for 2006 to date. The number of reported terminations of pregnancy was 36 in 2000, 26 in 2005, and 22 in 2006 (Figure 14).

Over the period 2000-2006, the number of cases of isolated cleft palate ranged from 60 to 90 per year, and for total cleft lip (including cases of cleft lip and cleft palate) from 66 to 88 per year. Termination of pregnancy was usually associated with other defects such as neural tube defects, chromosomal abnormalities, or multiple abnormalities in addition to the cleft lip and/or cleft palate.
The reported number of live born and stillborn infants with chromosomal defects was 219 in 2000 and 179 in 2005. The number of reported terminations of pregnancy associated with chromosomal defects rose from 193 in 2000 to 233 in 2005. The number of infants born with Down syndrome was 118 in 2000 and 73 in 2005, while the number of reported terminations of pregnancy associated with Down syndrome rose from 96 in 2000 to 138 in 2005 (Figures 15 and 16).

In 2000, 20 live born infants were reported to have a diaphragmatic hernia, and there were 2 terminations of pregnancy associated with this condition. In 2005, there were 28 live born infants reported with a diaphragmatic hernia, and there were no terminations of pregnancy (Figure 17).

\section{TABLE 152}

SELECTED BIRTH DEFECTS BY YEAR, NSW 2000-2006\#

\begin{tabular}{|c|c|c|c|c|c|c|c|c|c|c|c|c|c|c|}
\hline \multirow[t]{2}{*}{ Birth defect } & \multicolumn{2}{|c|}{2000} & \multicolumn{2}{|c|}{2001} & \multicolumn{2}{|c|}{2002} & \multicolumn{2}{|c|}{2003} & \multicolumn{2}{|c|}{2004} & \multicolumn{2}{|c|}{2005} & \multicolumn{2}{|c|}{2006} \\
\hline & No. & $\begin{array}{r}\text { Rate/ } \\
1000\end{array}$ & No. & $\begin{array}{r}\text { Rate/ } \\
1000\end{array}$ & No. & $\begin{array}{r}\text { Rate/ } \\
1000\end{array}$ & No. & $\begin{array}{r}\text { Rate/ } \\
1000\end{array}$ & No. & $\begin{array}{r}\text { Rate/ } \\
1000\end{array}$ & No. & $\begin{array}{r}\text { Rate/ } \\
1000\end{array}$ & No. & $\begin{array}{r}\text { Rate/ } \\
1000\end{array}$ \\
\hline Neural tube defects & 77 & 0.9 & 71 & 0.8 & 62 & 0.7 & 67 & 0.8 & 58 & 0.7 & 66 & 0.73464 & 52 & 0.6 \\
\hline Anencephalus & 29 & 0.3 & 25 & 0.3 & 20 & 0.2 & 18 & 0.2 & 16 & 0.2 & 19 & 0.21149 & 13 & 0.1 \\
\hline Spina bifida & 42 & 0.5 & 39 & 0.5 & 33 & 0.4 & 46 & 0.5 & 35 & 0.4 & 40 & 0.44524 & 32 & 0.3 \\
\hline Encephalocele & 13 & 0.1 & 8 & 0.1 & 10 & 0.1 & 7 & 0.1 & 8 & 0.1 & 8 & 0.08905 & 8 & 0.1 \\
\hline Cleft palate & 79 & 0.9 & 67 & 0.8 & 60 & 0.7 & 88 & 1.0 & 74 & 0.9 & 90 & 1.00178 & 39 & 0.4 \\
\hline Total cleft lip & 71 & 0.8 & 88 & 1.0 & 76 & 0.9 & 85 & 1.0 & 79 & 0.9 & 66 & 0.73464 & 69 & 0.7 \\
\hline Hypospadias & 191 & 2.2 & 173 & 2.0 & 133 & 1.6 & 171 & 2.0 & 150 & 1.8 & 146 & 1.62511 & 80 & 0.9 \\
\hline Limb reduction defects & 61 & 0.7 & 42 & 0.5 & 21 & 0.2 & 31 & 0.4 & 36 & 0.4 & 38 & 0.42297 & 39 & 0.4 \\
\hline Chromosomal abnormalities & 412 & 4.7 & 370 & 4.3 & 441 & 5.2 & 451 & 5.3 & 446 & 5.2 & 412 & 4.58593 & 226 & 2.5 \\
\hline Down syndrome & 214 & 2.5 & 180 & 2.1 & 221 & 2.6 & 227 & 2.6 & 232 & 2.7 & 211 & 2.34862 & 124 & 1.3 \\
\hline Renal agenesis and dysgenesis & 82 & 0.9 & 75 & 0.9 & 63 & 0.7 & 68 & 0.8 & 82 & 1.0 & 73 & 0.81256 & 58 & 0.6 \\
\hline Exomphalos & 28 & 0.3 & 22 & 0.3 & 22 & 0.3 & 20 & 0.2 & 28 & 0.3 & 15 & 0.16696 & 19 & 0.2 \\
\hline Gastroschisis & 20 & 0.2 & 23 & 0.3 & 18 & 0.2 & 19 & 0.2 & 16 & 0.2 & 19 & 0.21149 & 21 & 0.2 \\
\hline Diaphragmatic hernia & 22 & 0.3 & 28 & 0.3 & 23 & 0.3 & 21 & 0.2 & 30 & 0.4 & 28 & 0.31167 & 21 & 0.2 \\
\hline
\end{tabular}




\section{FIGURE 14}

NEURAL TUBE DEFECTS: CASES BY YEAR AND PREGNANCY OUTCOME, NSW 2000-2006

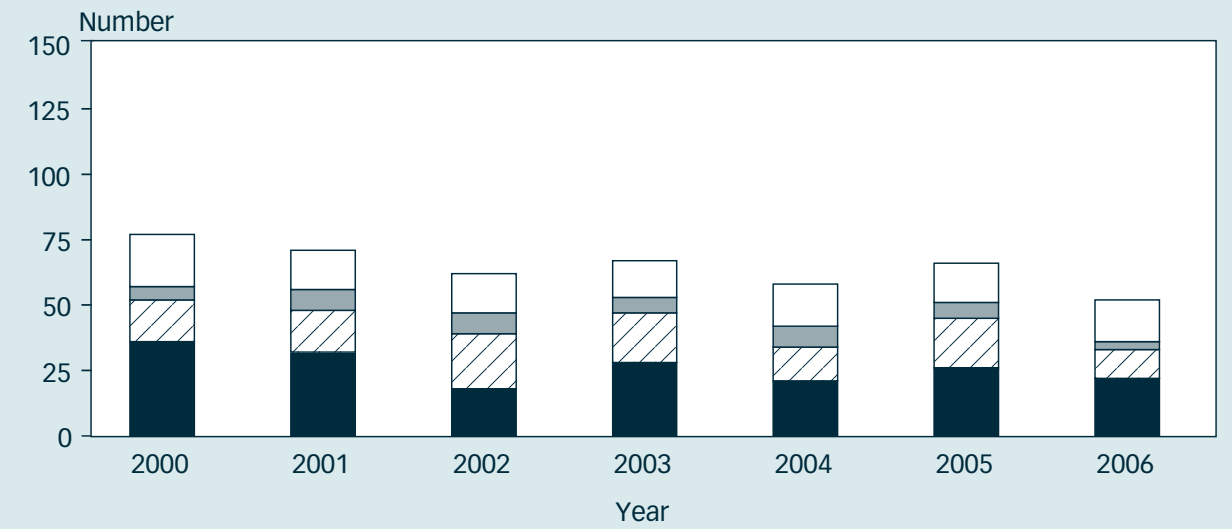

Termination of pregnancy $\square$ Stillbirth $\quad \square$ Livebirth - neonatal death $\square$ Liveborn surviving $>28$ days

Source: NSW Birth Defects Register. Centre for Epidemiology and Research. NSW Department of Health.

\# For 2000-2005, cases reported during pregnancy and up to one year of age are included. For 2006, cases reported during pregnancy

or at birth are reported.

\section{FIGURE 15}

CHROMOSOMAL ABNORMALITIES: CASES BY YEAR AND PREGNANCY OUTCOME, NSW 2000-2006

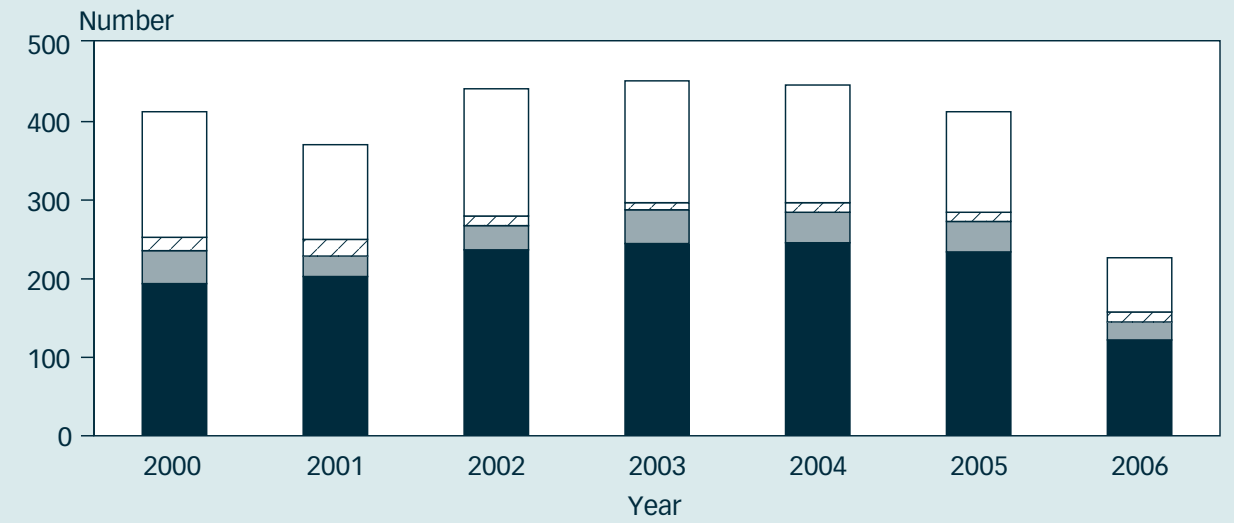

Termination of pregnancy $\quad \square$ Stillbirth $\quad \square$ Livebirth - neonatal death $\square$ Liveborn surviving $>28$ days

Source: NSW Birth Defects Register. Centre for Epidemiology and Research. NSW Department of Health.

\# For 2000-2005, cases reported during pregnancy and up to one year of age are included. For 2006, cases reported during pregnancy

or at birth are reported. 


\section{FIGURE 16}

DOWN SYNDROME: CASES BY YEAR AND PREGNANCY OUTCOME, NSW 2000-2006

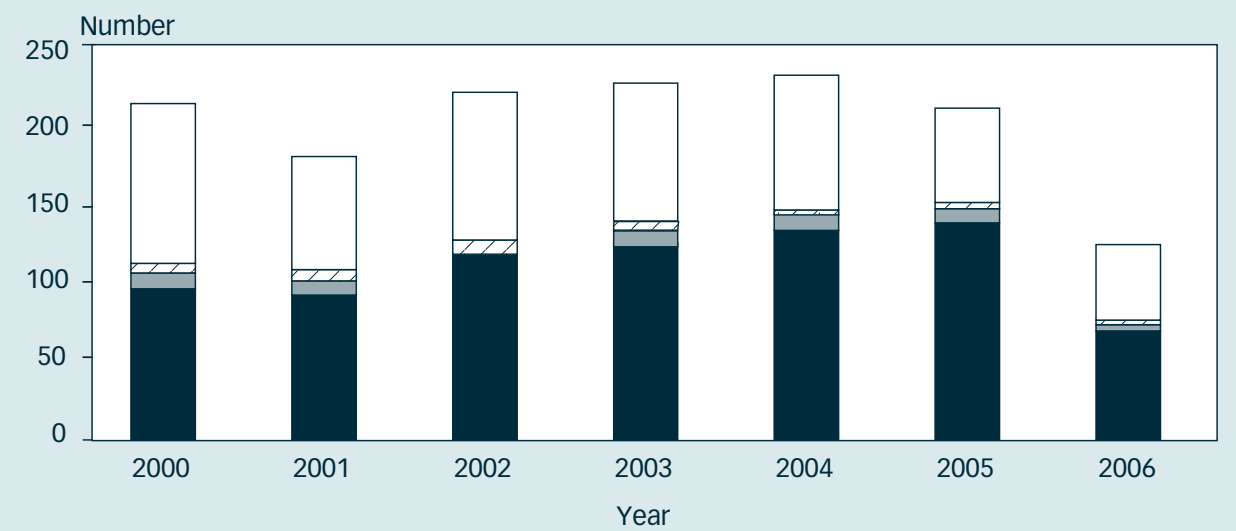

Termination of pregnancy $\square$ Stillbirth $\square$ Livebirth - neonatal death $\square$ Liveborn surviving $>28$ days

Source: NSW Birth Defects Register. Centre for Epidemiology and Research. NSW Department of Health.

\# For 2000-2005, cases reported during pregnancy and up to one year of age are included. For 2006, cases reported during pregnancy

or at birth are reported.

\section{FIGURE 17}

DIAPHRAGMATIC HERNIA CASES BY YEAR AND PREGNANCY OUTCOME, NSW 2000-2006*

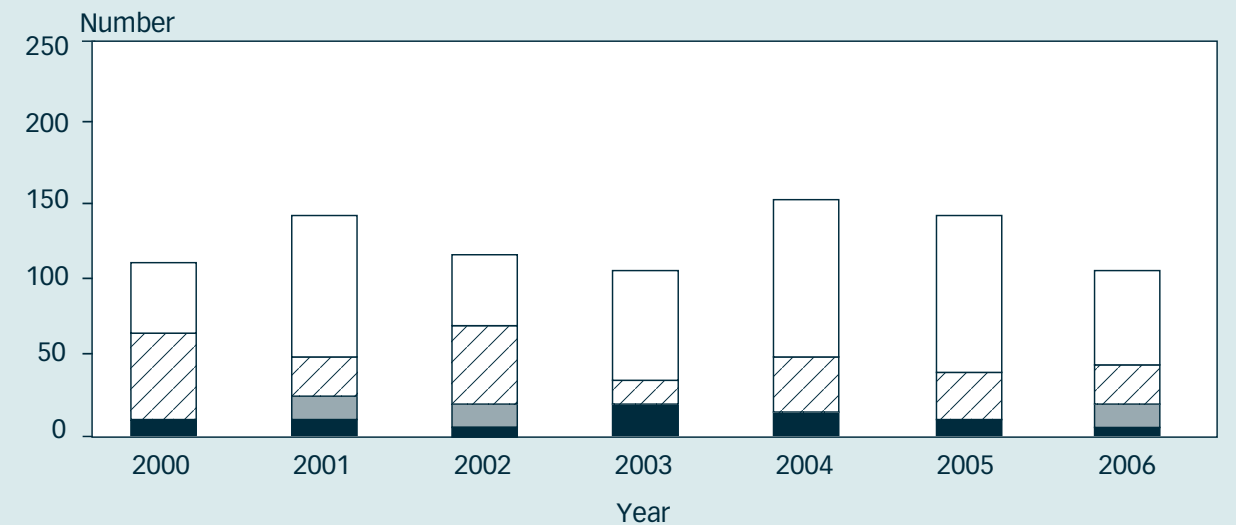

Termination of pregnancy $\quad \square$ Stillbirth $\quad \square$ Livebirth - neonatal death $\square$ Liveborn surviving $>28$ days

Source: NSW Birth Defects Register. Centre for Epidemiology and Research. NSW Department of Health.

\# For 2000-2005, cases reported during pregnancy and up to one year of age are included. For 2006, cases reported during pregnancy

or at birth are reported. 


\section{Birth defects by NSW health areas}

Crude rates of reported birth defects for NSW health areas and rates standardised for maternal age are shown in Table 153. The denominator population includes live births and stillbirths among NSW residents as reported to the MDC. The rate of birth defects increases with increasing maternal age (Table 149). In order to allow direct comparison of geographic areas, rates have been standardised to the maternal age distribution of births in NSW in 1991.

In interpreting birth defect rates among NSW areas, it should also be noted that infants with birth defects who are born to mothers resident in areas close to interstate borders may be transferred interstate for care and therefore may not be reported to the BDR.
Over the period 2000-2006, standardised rates of reported birth defects were lowest in the Greater Southern Area and highest in the Hunter and New England Area. Review of cases showed slightly increased reported rates of a range of birth defects in the Hunter and New England Area compared to NSW overall including: unstable hips (but not dislocated hips), first degree hypospadias, undescended testis, obstructive defects of the renal pelvis and ureter, spina bifida, ventricular septal defect, atrial septal defect and heart valve defects. There was no clustering by small geographic area. The range and pattern of these defects suggests that reporting of congenital abnormalities is better in the Hunter and New England Health Area compared with NSW as a whole.

\section{TABLE 153}

\section{BIRTH DEFECTS IN NSW HEALTH AREAS, 2000-2006\#}

\begin{tabular}{|c|c|c|c|c|c|c|c|c|c|c|c|c|c|}
\hline \multirow[t]{3}{*}{ Health Area } & \multicolumn{13}{|c|}{ Year } \\
\hline & \multicolumn{3}{|c|}{ 2000-2004 } & \multicolumn{3}{|c|}{2005} & \multicolumn{3}{|c|}{2006} & \multicolumn{4}{|c|}{$2000-2006$} \\
\hline & $\begin{array}{l}\text { No. of } \\
\text { cases }\end{array}$ & $\begin{array}{r}\text { Crude } \\
\text { rate per } \\
1000 \\
\text { births }\end{array}$ & $\begin{array}{r}\text { Stand- } \\
\text { ardised } \\
\text { rate per } \\
1000 \\
\text { births }\end{array}$ & $\begin{array}{l}\text { No. of } \\
\text { cases }\end{array}$ & $\begin{array}{r}\text { Crude } \\
\text { rate per } \\
1000 \\
\text { births }\end{array}$ & $\begin{array}{r}\text { Stand- } \\
\text { ardised } \\
\text { rate per } \\
1000 \\
\text { births }\end{array}$ & $\begin{array}{l}\text { No. of } \\
\text { cases }\end{array}$ & $\begin{array}{r}\text { Crude } \\
\text { rate per } \\
1000 \\
\text { births }\end{array}$ & $\begin{array}{r}\text { Stand- } \\
\text { ardised } \\
\text { rate per } \\
1000 \\
\text { births }\end{array}$ & $\begin{array}{l}\text { No. of } \\
\text { cases }\end{array}$ & $\begin{array}{r}\text { Crude } \\
\text { rate per } \\
1000 \\
\text { births }\end{array}$ & $\begin{array}{r}\text { Stand- } \\
\text { ardised } \\
\text { rate per } \\
1000 \\
\text { births }\end{array}$ & $\begin{array}{r}99 \% \\
\text { confidence } \\
\text { interval }\end{array}$ \\
\hline Sydney South West & 2270 & 23.4 & 21.0 & 373 & 18.6 & 16.3 & 202 & 9.7 & 8.5 & 2845 & 20.7 & 18.5 & $17.5-19.5$ \\
\hline $\begin{array}{l}\text { South Eastern } \\
\text { Sydney \& Illawarra }\end{array}$ & 1703 & 24.1 & 20.8 & 314 & 21.1 & 18.9 & 174 & 11.4 & 11.2 & 2191 & 21.7 & 19.1 & $17.8-20.4$ \\
\hline Sydney West & 1840 & 22.8 & 20.9 & 297 & 17.2 & 15.0 & 172 & 9.8 & 9.6 & 2309 & 20.0 & 18.3 & $17.2-19.4$ \\
\hline $\begin{array}{l}\text { Northern Sydney } \\
\& \text { Central Coast }\end{array}$ & 1537 & 23.2 & 19.4 & 309 & 22.2 & 15.6 & 161 & 11.2 & 9.8 & 2007 & 21.2 & 17.4 & $16.1-18.8$ \\
\hline $\begin{array}{l}\text { Hunter \& New } \\
\text { England }\end{array}$ & 1401 & 28.0 & 25.4 & 302 & 28.6 & 25.6 & 137 & 12.8 & 11.5 & 1840 & 25.8 & 23.4 & $21.9-24.9$ \\
\hline North Coast & 469 & 19.8 & 18.8 & 90 & 17.9 & 16.4 & 49 & 9.5 & 8.3 & 608 & 17.9 & 16.9 & $15.1-18.8$ \\
\hline Greater Southern & 375 & 18.4 & 16.5 & 83 & 20.5 & 15.3 & 31 & 7.5 & 8.0 & 489 & 17.1 & 15.1 & $13.3-17.1$ \\
\hline Greater Western & 424 & 21.1 & 19.8 & 82 & 20.3 & 18.8 & 57 & 13.9 & 12.9 & 563 & 19.9 & 18.7 & $16.6-20.9$ \\
\hline TOTAL NSW & 10019 & 23.4 & 20.9 & 1850 & 20.6 & 17.7 & 983 & 10.7 & 9.9 & 12852 & 21.0 & 18.8 & $18.3-19.3$ \\
\hline
\end{tabular}

Source: NSW Birth Defects Register. Centre for Epidemiology and Research. NSW Department of Health.

\# For 2000-2005, cases reported during pregnancy and up to one year of age are included. For 2006, cases reported during pregnancy or at birth are reported. 